\title{
Obituaries
}

Obituaries should be submitted by email to Laura Pacey at I.pacey@nature.com.

All submitted obituaries should be 350 words maximum in length (apart from obituaries for past presidents of the BDA where the length should be $700-800$ words).

Content of the obituary is down to the individual author, and the approval of the family should be given for the obituary prior to submission to the $B D J$.

\section{PETER THOMAS HEFFER}

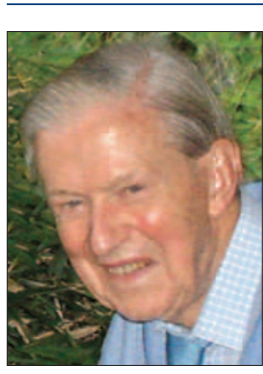

Peter was born in Marylebone on 1 November 1919. During WW2 he served in the RAF and became friendly with Max Horsnell, later Dental Dean at the London Hospital. He considered medicine but Horsnell encouraged him towards dentistry. After the war Peter stayed in the service to take the Forces Preliminary Examination. He studied at the London, qualifying LDSRCS in March 1954.

He was greatly influenced by the enigmatic Horsnell towards a lifetime's interest in dentistry for disadvantaged children. After qualification Peter worked in general practice then specialised in treating children. As a part-time lecturer in children's dentistry at the London, he taught undergraduates the need for a sound ethical approach to clinical practice. He initially provided treatment on a voluntary basis at Dr Barnardo's Homes for orphans in Barkingside with which the London had a longstanding dental relationship begun by Sir Evelyn Sprawson. By 1964 Peter developed a comprehensive service for the children at which point the London broke its formal contact with the home.

Later Peter confined himself to orthodontics and worked for the Hackney school service. After the 1974 NHS reorganisation he crossed the river to become orthodontist to the Lambeth, Southwark and Lewisham community services.

With Horsnell's encouragement he was involved with the London Society for the Study of Children's Dentistry, later the British Paedodontic (children's dentistry) Society.

Peter married Mair Jones on 3 June 1944 and the marriage lasting until his death on 15 December 2011. They had no children but there were three nieces and two nephews. Peter often referred to Fiona as the daughter they never had. They loved the theatre and music and were serious balletomanes, sometimes attending three performances a week.

In the past six months Peter's health deteriorated, getting pneumonia and suffering a stroke from which he died. Many relatives and friends attended the Requiem Mass celebrated at the Church of St Anselm and St Cecilia's in Kingsway.

Peter is survived by Mair and his brother Michael. He was extremely religious and his family will take comfort from his being elevated to a better place.

Stanley Gelbier, Stephen Osborne

\section{COLIN FORSYTH OBE}

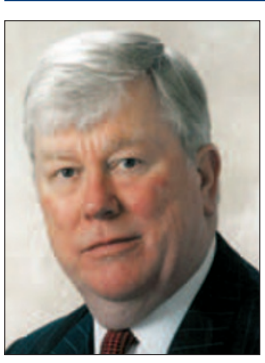

Colin became a household name to countless members of the dental profession in his role as part-time chairman of the Dental Practice Board for England and

Wales, a post he held with distinction for nearly nine years and for which he was recognised with the award of the OBE in 2001. Despite receiving many accolades Colin remained a true gentleman, always courteous, full of boundless energy and enthusiasm, but always retaining an impish sense of humour and fun.

Colin, who died on 7 0ctober 2011 after a short illness, was born in Teignmouth, Devon in 1940 and went to school in Uppingham which was to become his home town for most of his life. A couple of years after qualifying from Guy's Hospital Dental School he joined his father in the well established family practice in Kettering where for the next 30 years he witnessed and embraced fundamental changes in dental practice before retiring from dentistry in 2009.

His sense of vocation was strong and in 1988 he became visiting dentist to HM Prison Gartree and later consultant to the HM Prison Service. Colin's analytical mind and vast experience of life also equipped him to be an invaluable member of the Criminal Injuries Compensation Appeal Panel from 2000.

Politics flowed in his veins and he held various posts in the General Dental Services Committee and the South Mercia Branch of the BDA. He also branched out into local politics and was chairman of Rutland District Council and a member of Rutland County Council, posts to which he brought wise counsel and sound judgement.

Colin was a devoted husband to his wife of 45 years, Sarah, whose appointment as High Sheriff of Rutland brought him great pride as did his children Hamish and Charlotte and his five grandchildren.

Colin will be greatly missed but fondly remembered by all. 